Maffulli N, Caine DJ (eds): Epidemiology of Pediatric Sports Injuries: Team Sports.

Med Sport Sci. Basel, Karger, 2005, vol 49, pp 62-85

\title{
Gridiron Football Injuries
}

\author{
Michael J. Stuart \\ The Mayo Clinic, Department of Orthopedic Surgery, Rochester, Minn., USA
}

\begin{abstract}
Objective: To review the available football epidemiology literature to identify risk factors, facilitate injury prevention and uncover deficiencies that may be addressed by future research. Data Sources: A literature search of Sports Discus (1940-2003), Eric (1967-2003), EMBASE (1988-2003), MEDLINE (1966-2003), CINAHL (1984-2003), and Web of Science (1993-2003) identified the published articles on American football in athletes of high school age and younger. Main Results: Injury rate increases with the level of play (grade in school), player age, and player experience. The lower extremity (knee and ankle joints) is most frequently injured. Football injuries are much more common in games than in practice, and occur to players who are being tackled, tackling or blocking. Most injuries are mild, including contusion, strain and sprain. Rule changes with the prohibition of initial contact with the helmet or face-mask reduced catastrophic head and neck injuries. Conclusion: Although no sport or recreational activity is completely risk-free, football epidemiology research is critical to injury prevention. The existing medical literature provides some valuable insights, but an increased emphasis on prospective research is required to test the efficacy of preventative measures. Quality research may contribute to a reduction in football injury risk by defining the role of player conditioning and strength training, coaching of safety fundamentals, avoidance of dangerous activities, as well as proper medical supervision and care. Sports medicine personnel, coaches, and officials must strive to minimize injuries through progressive education, improved coaching techniques, effective officiating, and equipment modifications.
\end{abstract}

Copyright $(2005$ S. Karger AG, Basel

\section{Introduction}

Thirty-five million children and young adults in the United States participate in sports [1]. One of every fourteen teenagers presenting to the emergency room following a traumatic event has a sports-related injury, and American football is the most common precipitating athletic activity [2]. Approximately 1.2 million injuries occur each year as a result of 1.5 million athletes participating in 
organized American football [3]. The knee and ankle are most commonly injured in this collision and contact team sport, but football has also been associated with catastrophic injuries involving the brain and cervical spine [4].

The sports medicine community has attempted to document the risks and the mechanisms of injury in the game of gridiron football, especially concussion, spinal cord trauma and death [3,5-11]. The nature of available reports range from surveys, which estimate the absolute number of injuries, to prospective cohort analyses that identify risk factors and suggest preventative measures [12-15]. The bulk of the literature concerning gridiron football injuries has focused on the high school age athlete and older $[8,11,15-22]$. Few studies have investigated the risk of participation in American football at the youth level, but injury rate and severity appears surprisingly low when compared to those competitors who have passed through puberty [14, 21, 23-27].

\section{Problem Statement}

A review of American football epidemiology research permits administrators, sports medicine professionals, coaches and players to identify risk factors and hopefully facilitate injury prevention. This information also allows parents and their children to make informed decisions about football participation [28]. The published articles on American football in athletes of high school age and younger were identified by searching Sports Discus (1940-2003), Eric (1967-2003), EMBASE (1988-2003), MEDLINE (1966-2003), CINAHL (1984-2003), and Web of Science (1993-2003).

Two major limitations to cross-investigation comparisons are the definition of what exactly is an injury and what constitutes risk. The numerator refers to the injury events and the denominator reflects the participating players at risk $[29,30]$. An epidemiological survey of the literature on high school football injuries [31] revealed numerous methodological problems. Simply put, the calculated injury rate is only good at the identification of cases (numerator) and the identification of the population-at-risk (denominator). Lack of a clear definition of injury, standardized forms, strict record keeping and precise diagnosis results in detection and recall bias. The specific definition of injury is critical, since studies that record all injuries, including minor trauma, can overestimate risk. Injury detection by telephone interview or questionnaire is fraught with inaccuracy. Emergency department chart review may not identify the injured athletes who sought evaluation elsewhere or did not require treatment [32]. Data from insurance files uncovers only the claims-made injuries, which also encourages under-reporting [33]. Parents and coaches may not have the experience to correctly diagnose and report all injuries [23]. Surveys and questionnaires have poor compliance and are fraught with error. 
Most published investigations of high school and youth football injuries have not considered the population-at-risk, but have merely reported the number of participants. Injury risk factors cannot be analyzed without simultaneous measurement of injury exposure [34]. The total number of participants used as the denominator fails to account for the time of exposure, which is a key component for a meaningful analysis. Defining the population-at-risk as the players on the team roster at the start of the season does not take into consideration player attrition (transfer bias) or limited playing time (low exposure). Estimation of collective player exposure by calculating the number of players, the number of games and practices, and the approximate length of each practice and games is inaccurate. This method also implies that each practice is the same and each player participates equally in each practice and game.

Football is a noncontinuous participation sport, and interruption of competition between plays makes injury risk assessment according to playergames and player-plays more pragmatic than player-hours. The actual playing time during a 40-minute youth football game (four 10-minute quarters) has been measured at approximately eight minutes [14]. Measurement of exposure to injury by recording the offensive, defensive and special teams' plays is more sensitive. This technique of injury analysis and reporting is similar to tracking the number of bicycle trips or gymnastics maneuvers and should be more accurate in calculating injury rates. Even well-designed studies often use methods of injury incidence calculation that typically do not account for more than one injury per incident or more than one injury per player.

\section{Incidence of Injury}

Risk of injury or 'incidence' is determined according to established principles of epidemiological research. Few studies to date have accurately addressed the risk of injury during football game participation, and comparison to other sports or free play is difficult. Participation in competitive football, especially at the youth level, can be difficult for some players and their parents because of a perceived high injury risk. The available literature both supports and refutes this perception.

A prospective study of 6-17-year-old athletes participating in six supervised sports on a military base revealed that football players sustained twice as many orthopedic injuries as any other sport [35]. However, these researchers also found that unsupervised recreational activities contributed twice as many extremity injuries as those occurring during organized sporting events. Baseline injury rate was studied in a cohort of children aged 7-13 participating in 
community-organized baseball, softball, soccer and football [36]. No differences were detected over a period of two seasons when the injury risk was expressed as injuries per 100 athlete-exposures. Football participation was associated with a higher risk of serious injury (fracture, dislocation, concussion). High school athletes who played football were not at higher risk for injury when compared to students participating in other activities [18]. Junior league organized football was safer than free play based on an analysis of 70 teams [24]. Data collected on athletes in the fourth with grades [14] revealed that the risk of injury in youth football did not appear greater than other recreational or competitive sports. Godshall [37] observed approximately 2,300 Junior League football players over a 17 -year period and identified only 2 major injuries. His risk-benefit analysis concluded that the leadership, discipline, self-sacrifice, and sportsmanship learned outweighed the prospect of injury.

On the other hand, surveillance of injuries to high school athletes by athletic trainers revealed that football had the highest injury rate $(8.1$ per 1,000 athlete-exposures) and volleyball had the lowest (1.7 per 1,000 athleteexposures) [38]. Another one-year study of 1,283 high school athletes identified 280 injuries with football responsible for $61 \%$ [39]. Football was also responsible for the highest percentage ( 81 injuries/100 participants) of injuries among high school athletes in the Seattle metropolitan area [22], and high school football players were 6 times more likely to have knee surgery compared to the general population [16].

\section{High School}

The data on injury rates affecting high school football players are summarized in table 1. Review of table 1 identifies one retrospective study [8] and six prospective $[15,16,18,19,38,39]$ studies. Surveys and insurance or emergency record reviews were not included. The study duration ranged from one to nine seasons, although most studies followed the athletes for two to four seasons. Definition of injury varied, but typically included time-lost from participation as one of the criteria. Exposure was measured in only three of the studies by estimating the collective player participation in practices and games. Cross-study comparisons are not reliable if the definition of injury and/or measurement of exposure are inconsistent. Injury rates in the Powell and Barber-Foss [38] and Turbeville [15] studies indicate a range of 13.1-26.4 injuries per 1,000 game exposures and 1.3-5.3 injuries per 1,000 practice exposures. These discrepancies may reflect differences in study design rather than a true difference in injury incidence.

Thompson [31] identified 32 total injuries in 36 players during a single high school football season, but many trivial injuries were likely included. 
Table 1. High school football injuries

\begin{tabular}{|c|c|c|c|c|c|c|c|}
\hline & $\begin{array}{l}\text { Study } \\
\text { design }\end{array}$ & $\begin{array}{l}\text { Study } \\
\text { duration }\end{array}$ & $\begin{array}{l}\text { Number of } \\
\text { injuries/ } \\
\text { players }\end{array}$ & $\begin{array}{l}\text { Definition } \\
\text { of injury }\end{array}$ & $\begin{array}{l}\text { Measurement } \\
\text { of exposure }\end{array}$ & $\begin{array}{l}\text { Data } \\
\text { collection } \\
\text { method }\end{array}$ & Injury rate \\
\hline Moretz [18] & $\begin{array}{l}\text { Prospective } \\
\text { cohort }\end{array}$ & $\begin{array}{l}\text { Two } \\
\text { seasons }\end{array}$ & $241 / 903$ & $\begin{array}{l}\text { Time lost (altered } \\
\text { or lost practice } \\
\text { or game) }\end{array}$ & $\begin{array}{l}\text { None (estimated } \\
\text { total time at risk) }\end{array}$ & $\begin{array}{l}\text { Player telephone } \\
\text { interview }\end{array}$ & $\begin{array}{l}\text { ? } 0.51 \text { injuries/ } \\
\text { player/game } \\
\text { hour }\end{array}$ \\
\hline Olson [39] & $\begin{array}{l}\text { Prospective } \\
\text { cohort }\end{array}$ & $\begin{array}{l}\text { Nine } \\
\text { seasons }\end{array}$ & $478 / 1200$ & $\begin{array}{l}\text { Time lost } \\
\text { ( } \geq 2 \text { practices, } \\
\geq 1 \text { game })\end{array}$ & None & $\begin{array}{l}\text { Injury report } \\
\text { form }\end{array}$ & $?$ \\
\hline Culpepper [8] & $\begin{array}{l}\text { Retrospective } \\
\text { cohort }\end{array}$ & $\begin{array}{l}\text { Four } \\
\text { seasons }\end{array}$ & $1877 / ?$ & $\begin{array}{l}\text { Treatment } \\
\text { sought }\end{array}$ & None & $\begin{array}{l}\text { Clinic record } \\
\text { review }\end{array}$ & $?$ \\
\hline Prager [19] & $\begin{array}{l}\text { Prospective } \\
\text { cohort }\end{array}$ & $\begin{array}{l}\text { Four } \\
\text { seasons }\end{array}$ & $251 / 598$ & Time lost & None & $\begin{array}{l}\text { Player or } \\
\text { athletic trainer } \\
\text { report }\end{array}$ & $?$ \\
\hline DeLee [16] & $\begin{array}{l}\text { Prospective } \\
\text { cohort }\end{array}$ & $\begin{array}{l}\text { One } \\
\text { season }\end{array}$ & $2,228 / 4,399$ & $\begin{array}{l}\text { Any time lost, } \\
\text { physician } \\
\text { treatment, } \\
\text { head injuries }\end{array}$ & $\begin{array}{l}\text { Estimated } \\
\text { collective } \\
\text { exposure }\end{array}$ & $\begin{array}{l}\text { Athletic trainer } \\
\text { report }\end{array}$ & $\begin{array}{l}0.506 \text { injuries/ } \\
\text { athlete/year }\end{array}$ \\
\hline Powell [38] & $\begin{array}{l}\text { Prospective } \\
\text { cohort }\end{array}$ & $\begin{array}{l}\text { Three } \\
\text { seasons }\end{array}$ & $10,557 / ?$ & $\begin{array}{l}\text { Time lost (unable } \\
\text { to participate in } \\
\text { current practice or } \\
\text { game), fractures, } \\
\text { dental, brain } \\
\text { injuries }\end{array}$ & $\begin{array}{r}\text { Collective } \\
\text { exposure }\end{array}$ & $\begin{array}{l}\text { Athletic trainer } \\
\text { report }\end{array}$ & $\begin{array}{l}26.4 \text { injuries } \\
\text { per } 1,000 \text { game } \\
\text { exposures, } \\
5.3 \text { injuries } \\
\text { per } 1,000 \\
\text { practice } \\
\text { exposures }\end{array}$ \\
\hline Turbeville [15] & $\begin{array}{l}\text { Prospective } \\
\text { cohort } \\
\text { Age } 12-18\end{array}$ & $\begin{array}{l}\text { Two } \\
\text { seasons }\end{array}$ & $132 / 717$ & $\begin{array}{l}\text { Time lost (missing } \\
\text { a practice/game } \\
\text { or alteration } \\
\text { of or loss } \\
\text { consciousness) }\end{array}$ & $\begin{array}{l}\text { Estimated } \\
\text { collective } \\
\text { exposure } \\
\text { (total number } \\
\text { of players } \times \text { total } \\
\text { number of practices } \\
\text { and games) }\end{array}$ & $\begin{array}{l}\text { Coach or athletic } \\
\text { trainer report }\end{array}$ & $\begin{array}{l}13.1 \text { injuries } \\
\text { per } 1,000 \text { game } \\
\text { exposures, } \\
1.3 \text { injuries } \\
\text { per } 1,000 \\
\text { practice } \\
\text { exposures }\end{array}$ \\
\hline
\end{tabular}


Turbeville et al. [15] studied injury frequency and risk factors in high school football players. The football coach or an athletic trainer generated an injury report and telephone follow-up confirmed the injury type, location and treatment. Collective exposure was estimated by multiplying the total number of players by the total number of practices and games. Overall risk in this cohort measured 13.1 injuries per 1,000 game exposures and 1.3 injuries per 1,000 practice exposures. Since the actual amount of playing time was not recorded for each player, first-string players were analyzed to indirectly control for playing time. Multivariate analysis revealed that a positive injury history and increasing player experience were the only significant injury predictor variables. The authors concluded that the best predictor of injury was playing experience, not physical characteristics. Injury risk increased $40-60 \%$ for every year increase in experience; but experienced players may simply be at higher risk because they participate in more plays during each game.

\section{Youth}

Injury rate data for youth football are summarized in table $2[14,21,23,26]$. Surveys and insurance or emergency record reviews were not included. Only four prospective cohort studies were identified. Study duration ranged from one to two seasons and all used a time-loss definition of injury. In the two studies that measured exposure to injury, game injury rates were very similar. Stuart et al. [14] reported 8.5 and Turbeville et al. [23] 8.8 injuries per 1,000 player games respectively. Goldberg [26] gathered injury data by telephone interview and questionnaire on football players aged 9 to 14 . The prevalence of injury type and location are somewhat helpful, but no additional conclusions are possible without measurement of exposure time.

The prospective cohort observational analysis by Stuart et al. [14] during a single season showed that youth football injuries are uncommon, occurring once every 8.75 seasons per player. Strengths of this study include a clear definition of injury, standardized forms, strict record keeping and an orthopedic sports medicine physician on site to provide an accurate diagnosis. A coach from each team completed the game participation and exposure form and recorded the total number of offensive and defensive plays, kickoffs and punts for each team. These epidemiological principles foster injury identification with minimal detection and recall bias, along with simultaneous measurement of injury exposure. Overall risk in this cohort was 8.5 injuries per 1,000 playergames and 0.2 injuries per 1,000 player-plays.

Turbeville et al. [23] also reported on injury frequency and risk factors in middle school football players using the same study design as their high school project. First-string players were again studied to indirectly control for playing time. Overall risk in this cohort was 8.8 injuries per 1,000 game exposures, and 
Table 2. Youth football injuries

\begin{tabular}{|c|c|c|c|c|c|c|c|}
\hline & $\begin{array}{l}\text { Study } \\
\text { design }\end{array}$ & $\begin{array}{l}\text { Study } \\
\text { duration }\end{array}$ & $\begin{array}{l}\text { Number of } \\
\text { injuries/ } \\
\text { players }\end{array}$ & $\begin{array}{l}\text { Definition } \\
\text { of injury }\end{array}$ & $\begin{array}{l}\text { Measurement } \\
\text { of exposure }\end{array}$ & $\begin{array}{l}\text { Data } \\
\text { collection } \\
\text { method }\end{array}$ & Injury rate \\
\hline Goldberg [26] & $\begin{array}{l}\text { Prospective } \\
\text { cohort } \\
\text { Age 9-14 }\end{array}$ & $\begin{array}{l}\text { One } \\
\text { season }\end{array}$ & $67 / 436$ & $\begin{array}{l}\text { Time lost (greater } \\
\text { than or equal } \\
\text { to one day) }\end{array}$ & None & $\begin{array}{l}\text { Questionnaire } \\
\text { completed by } \\
\text { league personnel }\end{array}$ & $?$ \\
\hline Linder [21] & $\begin{array}{l}\text { Prospective } \\
\text { cohort } \\
\text { Age } 11-15\end{array}$ & $\begin{array}{l}\text { Two } \\
\text { seasons }\end{array}$ & $55 / 340$ & $\begin{array}{l}\text { Time lost (removal } \\
\text { from or missing } \\
\text { subsequent practice } \\
\text { or game) }\end{array}$ & None & $\begin{array}{l}\text { Coach } \\
\text { report }\end{array}$ & $?$ \\
\hline Stuart [14] & $\begin{array}{l}\text { Prospective } \\
\text { cohort } \\
\text { Age 9-13 }\end{array}$ & $\begin{array}{l}\text { One } \\
\text { season }\end{array}$ & $55 / 915$ & $\begin{array}{l}\text { Time lost (remainder } \\
\text { of the game), attention } \\
\text { of a physician, all } \\
\text { concussion, dental, } \\
\text { eye and nerve injuries }\end{array}$ & $\begin{array}{l}\text { Individual player } \\
\text { game participation, } \\
\text { number of plays/ } \\
\text { game for each } \\
\text { team }\end{array}$ & $\begin{array}{l}\text { Physician } \\
\text { examination }\end{array}$ & $\begin{array}{l}8.5 \text { injuries } \\
\text { per } 1,000 \\
\text { player-games, } \\
0.2 \text { injuries } \\
\text { per } 1,000 \\
\text { player-plays }\end{array}$ \\
\hline Turbeville [23] & $\begin{array}{l}\text { Prospective } \\
\text { cohort } \\
\text { Age } 10-15\end{array}$ & $\begin{array}{l}\text { Two } \\
\text { seasons }\end{array}$ & $64 / 646$ & $\begin{array}{l}\text { Time lost (missing } \\
\text { practice or game/head } \\
\text { injury with impaired } \\
\text { consciousness) }\end{array}$ & $\begin{array}{l}\text { Estimated } \\
\text { collective exposure } \\
\text { (total number of } \\
\text { players } \times \text { total } \\
\text { number of practices } \\
\text { and games) }\end{array}$ & $\begin{array}{l}\text { Coach or athletic } \\
\text { trainer report }\end{array}$ & $\begin{array}{l}8.8 \text { injuries per } \\
1,000 \text { game } \\
\text { exposures, } \\
1.0 \text { injuries per } \\
1,000 \text { practice } \\
\text { exposures }\end{array}$ \\
\hline
\end{tabular}


1.0 injury per 1,000 practice exposures. The incidence of game injury in the youth players is somewhat less than Turbeville et al. [15] reported in high school athletes (13.1 injuries per 1,000 game exposures) using a similar study design.

\section{Player Position}

Injuries occur to players who are being tackled, tackling or blocking. Therefore, running backs, lineman and linebackers have the highest injury rate [28]. Injuries causing a time loss of 48 hours were more prevalent for high school offensive players $(n=153)$ compared to defensive players $(n=98)$. Excluding specialty teams, high school tackles and linebackers sustained the most injuries based on a percentage of total injuries. No exposure data for players or positions was recorded [19]. Youth football running backs and lineman were at highest risk for injuries, especially to the knee [14, 23].

\section{Injury Characteristics}

\section{Injury Onset}

The overwhelming majority of injuries in both high school and youth football are sudden or acute. Little information is available on the incidence and mechanism of overuse injuries in these young athletes.

\section{Injury Location}

Injury location expressed as a percentage of total injuries is summarized for high school football studies in table $3[8,15,16,18,38,39]$ and for youth football studies in table $4[14,23,24,26]$. A review of table 3 indicated that the lower extremity is the most frequently injured body region (31-59\%) followed by the upper extremity (21-34\%). The knee (15-37\%) and ankle (11-27\%) joints are most susceptible to football trauma. Upper extremity injuries typically involve the shoulder (8-15\%), and wrist and hand (7-11\%). Table 4 shows a similar distribution for youth players with the majority involving the lower extremity (36-51\%) followed by the upper extremity $(25-41 \%)$. The knee (17-22\%) and ankle (10-17\%) are again most susceptible for the lower extremity, the wrist and hand (14-30\%) for the upper extremity. The ankle physes (distal tibial and fibular growth plates) are especially vulnerable for a fracture in skeletally immature athletes [14].

Although cervical spine injuries are uncommon in most studies, a preseason examination of 104 high school football players revealed a history of neck injury in 17, positive physical examination findings in 2 players, and radiographic abnormalities in 8 [40]. Seventy-four high school players were studied over two seasons in an attempt to identify all injuries to the cervical 
Table 3. High school injury location

\begin{tabular}{|c|c|c|c|c|c|c|c|}
\hline $\begin{array}{l}\text { Percentage of } \\
\text { total injuries }\end{array}$ & $\begin{array}{l}\text { Olson } \\
{[39] \mathrm{n}=478}\end{array}$ & $\begin{array}{l}\text { Moretz } \\
{[18] \mathrm{n}=241}\end{array}$ & $\begin{array}{l}\text { Culpepper } \\
{[8] \mathrm{n}=1,877}\end{array}$ & $\begin{array}{l}\text { DeLee } \\
{[16] \mathrm{n}=2,228}\end{array}$ & $\begin{array}{l}\text { Powell } \\
{[38] \mathrm{n}=10,557}\end{array}$ & $\begin{array}{l}\text { Turbeville } \\
{[15] \mathrm{n}=132}\end{array}$ & Range \\
\hline Head & $\Gamma$ & $\Gamma$ & 8 & 5 & & 7 & $\Gamma$ \\
\hline Neck & 10 & 6 & & 1 & 13 & 2 & $6-15$ \\
\hline Face & L & L & & 4 & 2 & 6 & L \\
\hline Back & 2 & 5 & 5 & 8 & & 4 & $2-8$ \\
\hline Trunk & 5 & & 3 & 1 & 9 & 1 & $1-9$ \\
\hline $\begin{array}{l}\text { Upper } \\
\text { extremity }\end{array}$ & 26 & 21 & 34 & 23 & 26 & 22 & $21-34$ \\
\hline Shoulder & 9 & 7 & 13 & 11 & & 9 & $7-11$ \\
\hline Upper arm & 1 & & 1 & & 12 & 2 & $1-2$ \\
\hline Lower arm & 1 & $<1$ & 2 & & & & $1-2$ \\
\hline Elbow & 2 & 3 & 3 & 4 & & & $2-4$ \\
\hline Wrist & & $\Gamma$ & 3 & & 14 & 3 & $8-15$ \\
\hline Hand & 13 & 10 & 12 & 8 & & 5 & $1-3$ \\
\hline Pelvis/groin & & & $<1$ & & & 3 & $2-17$ \\
\hline Hip & & 12 & 2 & 7 & 17 & & $31-50$ \\
\hline $\begin{array}{l}\text { Lower } \\
\text { extremity }\end{array}$ & 58 & 58 & 46 & 48 & 31 & 59 & $4-10$ \\
\hline Upper leg & 4 & 4 & 5 & & & 10 & $4-10$ \\
\hline Lower leg & 4 & & 4 & 8 & & & $4-8$ \\
\hline Knee & 37 & 22 & 22 & 20 & 15 & 20 & $15-37$ \\
\hline Ankle & & & 11 & 18 & & 27 & $11-27$ \\
\hline Foot & 12 & 22 & 4 & 2 & 16 & 2 & $2-4$ \\
\hline Other & 1 & 10 & $<1$ & & & & \\
\hline
\end{tabular}

spine. Eight neck injuries were documented, including six muscle strains, one 'stinger', and one transient neurapraxia.

\section{Situation}

The risk of injury appears to be greater in competition than in practice, both at the high school and youth levels. High school football injuries are much more common in games than in practice [15, 16, 18, 40]. Moretz et al. [18] found the risk of injury for Oklahoma high school football players to be 18 times higher in a game that is a practice. The risk of injury in youth football is also higher in games, but injury incidence appears less than high school reports [14, 23]. Inconsistency in exposure measurement techniques and different expressions of injury rate make comparison of the available research difficult. Turbeville et al. $[15,23]$ reported a 10 -fold increased risk of game injury (13.1 injuries per 1,000 game exposures) than in practice (1.3 injuries per 1,000 practice exposures) 
Table 4. Youth injury location

\begin{tabular}{|c|c|c|c|c|c|}
\hline $\begin{array}{l}\text { Percentage of } \\
\text { total injuries }\end{array}$ & $\begin{array}{l}\text { Roser [24] } \\
\mathrm{n}=48\end{array}$ & $\begin{array}{l}\text { Goldberg [26] } \\
\mathrm{n}=67\end{array}$ & $\begin{array}{l}\text { Stuart [14] } \\
\mathrm{n}=55\end{array}$ & $\begin{array}{l}\text { Turbeville [23] } \\
\mathrm{n}=64\end{array}$ & Range \\
\hline $\begin{array}{l}\text { Head } \\
\text { Face }\end{array}$ & 8 & 10 & 7 & 2 & $2-10$ \\
\hline Neck & & & & & \\
\hline Back & 5 & 3 & 9 & 9 & $3-9$ \\
\hline Trunk & 6 & 5 & 5 & 6 & $5-6$ \\
\hline Upper extremity & & 32 & 25 & 41 & $25-41$ \\
\hline $\begin{array}{l}\text { Shoulder } \\
\text { Upper arm }\end{array}$ & 2 & 5 & 7 & & $5-7$ \\
\hline $\begin{array}{l}\text { Elbow } \\
\text { Lower arm }\end{array}$ & 1 & 6 & 4 & 11 & $4-6$ \\
\hline Wrist & 7 & & 9 & 17 & $14-30$ \\
\hline Hand & 9 & 21 & 5 & 13 & $5-13$ \\
\hline Pelvis/groin & & & 2 & 3 & $2-3$ \\
\hline Hip & & 3 & & & 3 \\
\hline Lower extremity & & 47 & 51 & 36 & $36-51$ \\
\hline Upper leg & & & 5 & & {$[2-10$} \\
\hline Lower leg & & & 5 & 2 & L \\
\hline Knee & 8 & 22 & 20 & 17 & $17-22$ \\
\hline Ankle & & 10 & 15 & 17 & $10-17$ \\
\hline Foot & & 15 & 4 & & $4-15$ \\
\hline Other & & & 2 & & \\
\hline
\end{tabular}

in high school players and almost 9-fold increased risk of game injury (8.8 injuries per 1,000 game exposures) than in practice (1.0 injury per 1,000 practice exposures) in youth players.

\section{Chronometry}

The risk of injury was 510 per 1,000 player-game-hours of exposure compared to 150 per 1,000 player-practice-hours during the preseason and 28 per 1,000 player-practice-hours during the season [18]. These rates suggest that injuries are 5.4 times more likely in preseason practice and 18.2 times more likely in games than in inseason practice.

\section{Injury Severity}

Most youth football injuries are mild, and the most common type is a contusion. Severity of injury is typically based on time loss until return to participation. 
Table 5. High school injury type

\begin{tabular}{|c|c|c|c|c|c|c|}
\hline $\begin{array}{l}\text { Perncetage of } \\
\text { total injuries }\end{array}$ & Moretz [18] & Olson [39] & Culpepper [8] & DeLee [16] & Powell [38] & Turbeville [15] \\
\hline Sprain & 40 & 21 & 32 & 45 & 32 & \\
\hline Strain & 22 & & 12 & & 21 & 54 \\
\hline Contusion & 18 & 14 & 25 & 21 & & 17 \\
\hline Fracture & & 24 & 11 & 7 & 8 & 11 \\
\hline Dislocation & 13 & 8 & 2 & 3 & & 5 \\
\hline Concussion & & 9 & 1 & 5 & & 6 \\
\hline Laceration & & & $<1$ & 16 & & 1 \\
\hline Dental & & & & 2 & & \\
\hline Other & 7 & 37 & 16 & & 39 & 6 \\
\hline
\end{tabular}

Table 6. Youth injury type

\begin{tabular}{|c|c|c|c|c|c|}
\hline $\begin{array}{l}\text { Percentage of } \\
\text { total injuries }\end{array}$ & Roser [24] & Goldberg [26] & Linder [21] & Stuart [14] & Turbeville [23] \\
\hline Sprain & Г & 34 & & 9 & \\
\hline Strain & 35 & 12 & 45 & 20 & 55 \\
\hline Contusion & 17 & 22 & 33 & 60 & 17 \\
\hline Fracture & 35 & 15 & 18 & 7 & 27 \\
\hline Dislocation & 1 & 4 & & & \\
\hline Concussion & 4 & 6 & & 2 & \\
\hline Laceration & $\Gamma$ & & 4 & & 2 \\
\hline Abrasion & 7 & 2 & & & \\
\hline \multicolumn{6}{|l|}{ Dental } \\
\hline Other & & 2 & & 2 & \\
\hline
\end{tabular}

An example of severity grading includes: mild (no limitations expected and either no time loss or players expected back at football within 3 days); moderate (athletes returned within 4-14 days); and severe (long-term sequelae expected and athletes expected to be out of football longer than 14 days).

\section{Injury Types}

Type of injury is summarized for high school players in table $5[8,15,16$, $18,38,39]$ and youth players in table $6[14,21,23,24,26]$. Most studies agree that minor injuries such as contusions, strains and sprains account for the bulk of all injuries. Turbeville et al. [15] showed that sprains and strains were most 
common in high school players, followed by contusions, and fractures. Injury type is very similar in high school and youth players, but the diagnostic terminology is not uniform. Sprains (9-45\%) and strains (12-22\%) combined account for approximately half of all injuries at both levels. Contusions represent between 14 and $60 \%$ and concussions only $1-9 \%$ of all injuries. Fractures occur in $7-24 \%$ of injuries to high school players and $7-35 \%$ of injuries to youth players. These fractures typically involve the growth plates of the wrist and ankle.

\section{Catastrophic Injury}

The likelihood of serious or catastrophic injury to youth football players is relatively small, but the risk increases for high school players. Mueller [41] defined catastrophic injury as any severe injury incurred during participation in a school-sponsored sport. These injuries are categorized as fatal, nonfatal (permanent or severe functional disability) or serious (no permanent functional disability, but severe injury). Sports injuries were further classified as direct or indirect. Direct injuries result from participation in the skills of the sport. Indirect injuries are caused by systemic failure as a result of exertion while participating in a sport activity or by complication secondary to a nonfatal injury.

\section{Fatalities}

The Annual Survey of Football Injury Research conducted by Mueller [42] registered 684 total football fatalities at all levels of play from 1945 through 1994. Most of the head injury fatalities $(\mathrm{n}=345,74.2 \%)$ and cervical spine fatalities $(\mathrm{n}=76,65.5 \%)$ occurred to high school players during games. The total number of fatalities climbed to 712 through 1999 [41]. Head injuries were responsible for $491(69 \%)$, cervical spine injuries for $116(16.3 \%)$, and other injuries for 105 (14.7\%).

Football head-related fatalities were most prevalent in junior and senior high school (75\%) largely due to the number of participants. The volume of high school players was estimated at 1.5 million as compared to 75,000 college players. Fatal head injuries usually occurred while tackling or being tackled during a game. Subdural hematoma was the most common diagnosis $(75 \%)$. The declining rate of football head-related fatalities is likely due to the 1976 rule change prohibiting initial contact with the head or face together with improved coaching of blocking and tackling techniques.

Cantu and Mueller [43] identified catastrophic American football head and spine injuries to high school, college, sandlot and professional players by analyzing epidemiological and medical data from 1977-1998. Catastrophic injuries were defined as death, brain or spinal cord injury, and cranial or spinal 
fracture. During this 11-year period, 118 football players died, 200 received a permanent spinal cord injury, and 66 suffered a permanent cerebral injury. Although the data were not broken down by age or level, 164 of the 200 cervical cord injuries were sustained by high school players and all 66 cerebral injuries occurred at the high school or college level.

\section{Concussion}

Despite the available data, most parents are uninformed about the risks of severe brain injury from their children playing high school football [44]. Athletic trainers recorded injury and exposure data for varsity athletes in 10 different sports at 235 high schools in a 1-year study [45]. Mild traumatic brain injury was diagnosed in 1,219 participants during the 3-year study period. Football accounted for 63.4 percent of the head injuries. Six cases of subdural hematoma and intracranial injury were identified in football players. Head injury rates were 11 times higher for games than for practice [46].

The incidence of concussion, common signs and symptoms as well as return-to-play criteria were analyzed from a survey of high school and collegiate football team athletic trainers [47]. Players who sustained a concussion were 3 times more likely to sustain a second concussion in the same season compared with uninjured players. Only $9 \%$ of concussed athletes lost consciousness, $86 \%$ developed a headache, and $31 \%$ returned to play on the same day. These observations are important, though based on a survey with a $62 \%$ response rate. Players, coaches and health care providers should be aware of the increased risk of a second concussion, and symptomatic athletes should never be allow to return to play.

Concussion appears to be relatively uncommon in youth football players $[14,24,26]$. Stuart et al. [14] recorded only one concussion when over 900 youth players aged 9-13 years were carefully followed during a single season. Turbeville et al. [23] identified only one mild head injury during a two-season study of middle school athletes.

\section{Injury Risk Factors}

Risk factors for injury can be intrinsic (personal), which represent characteristics of the specific player, or extrinsic (environment, equipment), from features out of the athlete's control (table 7). Determination of a true cause and effect relationship is very difficult because of numerous confounding variables. Increasing age and level of play appear to be associated with increase in injury incidence, but the relationship of body weight to injury risk remains unclear. 
Table 7. Injury risk factors

\begin{tabular}{ll}
\hline Intrinsic & Extrinsic \\
\hline Age & Conditioning \\
Grade in school & Field conditions \\
Tanner stage & Helmet type \\
Weight & Shoulder pad type \\
Body fat & Shoe type \\
Ligamentous laxity & Knee braces \\
Playing experience & \\
Psychosocial factors & \\
Dangerous activities & \\
\end{tabular}

\section{Intrinsic Factors}

Physical

Goldberg et al. [26] could not identify a correlation between injury risk and age in youth football players. However, Stuart et al. [14] found that the risk of injury to youth football players increased with level of play (grade in school) and player age. The risk of injury for an eighth grade player was 4 times greater than the risk of injury for a fourth grade player. Potential contributing factors included increased size, strength, speed, and aggressiveness.

Linder et al. [21] examined the relationship between sexual maturity (Tanner stage) and the incidence of injury in junior high school football players. The coach recorded an injury if a player was removed from a practice or a game. An overall injury rate of $16 \%$ was reported over two seasons. No serious or permanently disabling injuries occurred. Ten fractures, including five physeal injuries were diagnosed. Injuries were more prevalent in the older players who were also more physically mature (Tanner stages $3,4,5$ ). The authors admit that no direct conclusions can be drawn since individual exposure data were not collected.

Turbeville et al. [15] found that injured players were older, bigger, stronger, more experienced, and more likely to have sustained an injury in the previous season. The increased injury risk to the more experienced than uninjured players may actually reflect increased playing time, aggressiveness, or pubescence.

The North Carolina Study investigated junior and senior high school football injuries and also measured grip strength, physiologic maturation, ponderal index (weight relative to height), age, height, weight and body fat (subscapular skinfold) in 466 athletes. [48] Junior high players were less likely to be injured even though both levels had a wide variation in sexual maturation. The injured junior high players were lighter and less mature than noninjured teammates. In the author's opinion, $17 \%$ of all injuries were preventable, resulting from poor equipment, hazardous conditions or improper technique. 
Tanner's method of assessing sexual maturity was used in 340 male football players between the ages of 11 and 15 [21]. Each team's coach recorded injuries over two seasons if a player was removed from a practice or game and/or missed a subsequent practice or game. Tanner stages 5,4 , and 3 combined were associated with more injuries than Tanner stages 2 and 1 combined. Higher injury prevalence was evident with increasing age in these adolescent athletes. Player age was not controlled when testing for maturity as a risk factor. No exposure data were recorded, and the authors admit that the more mature athletes may have received more playing time. This study suggests that increasing sexual maturity may be a risk factor for adolescent football injuries.

Stuart et al. [14] compared the risk of injury for players above and below the mean body weight according to each grade level. A trend was evident that heavier players (individual body weight $>$ mean body weight) sustained more injuries than lighter players (individual body weight $<$ mean body weight). However, discriminate function analyses with weight predicting injury revealed no significant relationship between body weight and injury.

A prospective cohort analysis of 216 high school football players was designed to determine adiposity is associated with increased risk of injury. Athletic trainers recorded injuries as well as practice and game exposure time. Skinfold measurements revealed body fat range of 9.3-40.2\%. Eighty-six injuries occurred during 15,207 hours of total playing time for an injury rate of 0.026 injuries/player/1,000 hours. The trend was for players with more body fat, greater body weight, and greater body mass index to sustain lower extremity injuries. Body mass index greater than $26 \mathrm{~kg} / \mathrm{m}^{2}$ was consistently (except $\left.>34 \mathrm{~kg} / \mathrm{m}^{2}\right)$ associated with risk of lower extremity injury $(\mathrm{p}<0.05)$ [49].

Preseason height, weight, and triceps/subscapular skinfold were measured in 98 high school football players. During the season, certified athletic trainers recorded all injuries that required one of these players to miss at least one practice or game. Twenty-seven players ( $28 \%$ ) had the sum of skinfolds $\geq 95$ th percentile for age, but the overall prevalence was not significantly elevated when compared to player's $\leq 95$ th percentile. Although this study did not show an increased injury risk for obese football players, the high incidence of obesity in this athletic population was alarming [50].

No correlation was found between generalized ligamentous laxity and risk of knee or ankle ligament injury in 402 high school football players followed during a single season [51]. An abnormal preseason history or physical exam did not predict an increased risk of neck injury in these high school athletes [52].

\section{Psychosocial}

An investigation to test the relationship of anger/aggression, attention and stressful life events to injury and to determine whether the relationship of 
stressful events to injury is mediated by anger or by impaired vigilant or focused attention [53]. High school football players completed preseason measures of anger, vigilant attention or focused attention, and stressful life events and were then followed through one season to identify injuries. Logistic regression indicated that high anger directed outward $(\mathrm{p}<0.05)$ and low focused attention $(\mathrm{p}<0.01)$ increased injury risk, while stressful life events and vigilant attention interacted. Injury risk was elevated when recent stress was present $(\mathrm{p}<0.05)$ and increased as vigilance decreased, suggesting that stressful life events elevate injury risk by reducing vigilance.

Using the Life Event Scale for Adolescents, Coddington and Troxell [54] postulated that a player's mental or emotional state might increase the risk of injury. They based this opinion on the fact that high school players, who experienced more family instability, parental illness, separations, divorces and deaths were more likely to sustain a significant injury. Their review of coaches' records identified only 23 injuries. This small sample size and other possible confounding variables do not allow for a definite association between the player's emotions and risk factor of injury.

\section{Dangerous Activities}

'Spearing' involves flexing the neck and initiating contact with the top of the helmet. This dangerous manoeouvre has been associated with cervical spine fracture/dislocation and spinal cord injury. As a result, physicians, administrators and coaches preached avoidance of using the head as the primary point of contact in tackling and blocking. In January 1996, the National Alliance Football Rules Committee changed the rules to make 'butt-blocking' or 'facetackling' a personal foul (15-yard penalty). Coaches need to teach proper blocking and tackling techniques, which do not involve using the facemask or top of the helmet as the primary point of contact [55].

Despite these concerns, a survey of Louisiana high school football players identified an alarming rate of players who admitted to tackling with the top of their helmet. Eighty-three percent of those players stated that their coach taught these dangerous techniques [56].

A survey of Minnesota high school football coaches raised some concerns about players using illegal techniques such as butt blocking and face tackling [57].

Heck [58] reviewed 9 game films from a high school football season to establish the cumulative incidence per season of ball carrier spearing and concurrent defensive spearing by tacklers. During a single season, 167 incidents of ball carrier spearing ( 1 per 5.2 plays) and 72 incidents of concurrent defensive spearing (1 per 2.3 ball carrier spears) were identified. Despite the frequency of these rule violations, the game officials did not call any spearing penalties. The authors encourage officials to acknowledge these rule infractions and ask 
coaches to teach correct ball carrying, blocking and tackling techniques. Lack of rules enforcement is a modifiable risk factor for injury.

\section{Extrinsic Factors}

Training Methods or Conditions

Cahill et al. [59] compared the circumstances, number and severity of knee injuries during a 4-year period when football players participated in a preseason-conditioning program to the previous 4 years where no such program existed. The 5-6 week total body conditioning program included cardiovascular exercise, heat acclimatization, weight training, flexibility drills and agility exercises. The knee injury rate per 1,000 athletes was 68 for the no conditioning group and approximately 40 for the closely-supervised conditioning group. The operative rate per 1,000 players was 15.2 for the no conditioning group, 5.7 for the closely-supervised conditioning group and 2.3 for the less-supervised conditioning group. Early season knee injuries were reduced by $67 \%$ in the conditioning groups as compared to the no conditioning group. The authors concluded that preseason conditioning significantly reduces the early season knee injuries, the total number of knee injuries and the injury severity.

\section{Environment}

Wisconsin high school football teams were studied to determine the association of injury to field conditions [60]. 'Good' conditions were associated with the highest frequency of injury (3.3 injuries/game). 'Wet' and 'slippery' conditions were associated with the lowest rate (1.8 injuries/game). 'Hard' and 'muddy' conditions were associated with intermediate injury risk (2.3 and 2.1 injuries/game respectively). The authors postulated that wet and slippery conditions caused a reduction in player velocity and rotational stability of the shoe with the ground.

Adkison et al. [61] reported on 349 time-loss injuries from 424 high school football games played on natural grass and 236 games played on synthetic turf. Data analyses showed the injury rate for Astroturf ( 0.63 injuries per game) as compared to grass ( 0.51 injuries per game) and Tartan Turf ( 0.28 injuries per game). A prospective study of 26 high school football teams during 148 games played on grass and 80 games played on artificial turf revealed higher injury rate and severity on the synthetic surface [62]. The artificial turf studied was a single stadium where 12 of the schools played a majority of their games. The higher injury rates for the synthetic surface were predominantly sustained when the turf was dry, implicating increased traction as a potential risk factor.

The risk of knee and ankle injuries was reduced by $30 \%$ with resurfaced fields and regular cleats, and by $46 \%$ with resurfaced fields and soccer shoes when compared to schools with no changes. 


\section{Equipment}

Mueller and Blyth [63] reported on football injuries in 43 North Carolina high schools. Investigators visited each school during the preseason to evaluate the protective equipment of each player for make, fit and condition. The investigators then returned to the schools each week to interview each injured player. The North Carolina High School Football Injury Study suggested that specific brand name football helmets and shoulder pads were associated with higher injury 'rates', and a properly maintained playing surface combined with soccerstyle shoes reduced knee and ankle injures. The data provided are actually the prevalence of injury according to specific equipment brand. However, the author's conclusions are difficult to substantiate, since no exposure data were provided.

The relationship of football shoe design and injury rate encouraged regulations on the size and configuration of cleats. The conventional shoe, with seven $3 / 4 \times 3 / 8$ inch cleats, was associated with a higher incidence and severity of injury when compared to the soccer-style shoe with fourteen $3 / 8 \times 1 / 2$ inch cleats [64]. Four different football shoe cleat types were prospectively evaluated in high school football players to determine torsional resistance and the relationship with anterior cruciate ligament tears [65]. The edge design with longer, irregular cleats placed at the peripheral margin of the sole produced significantly higher torsional resistance and was associated with a significantly higher anterior cruciate ligament injury rate when compared to the flat, screw-in, and pivot disc designs.

Deppen and Landfried [66] compared high school football players at schools with mandatory or voluntary prophylactic knee brace use by tracking injuries, practice and game exposure. They found no differences in knee injury risk with and without bracing.

\section{Suggestions for Injury Prevention}

Youth and high school football injury risk may be reduced by player conditioning and strength training, the use of high quality, well-fit equipment, coaching of safety fundamentals, avoidance of dangerous activities, enforcement of existing rules, as well as proper medical supervision and care.

The 1976 rule change prohibiting initial contact with the head or face (spearing, face tackling and butt blocking) together with improved coaching of blocking and tackling techniques appears to have reduced the incidence of head and neck injuries. This rule change has also played a very important role in the decline of football fatalities. Head and cervical spine trauma resulting in footballrelated fatalities are depicted by decade from 1945 through 1994 in figure 1. The 


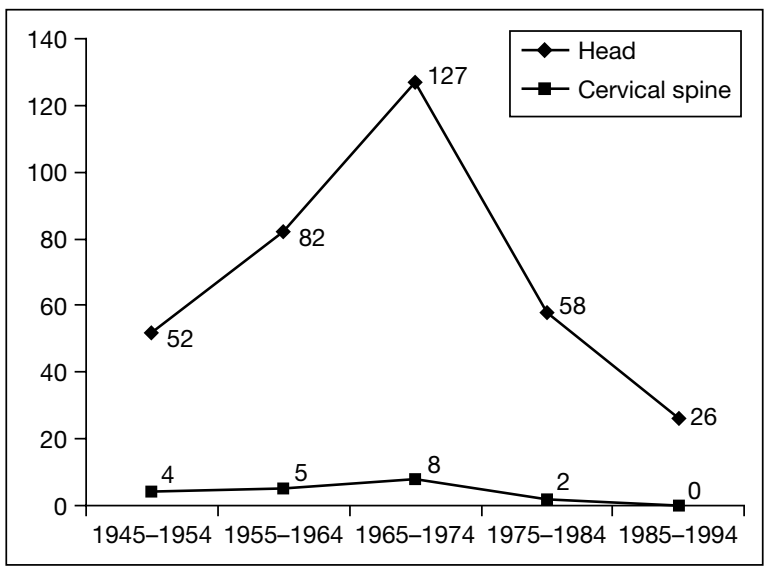

Fig. 1. High school football fatalities [45].

incidence of high school football fatalities over time is depicted in figure 2 . Mueller [41, 42] recommended additional measures to reduce head and neck fatalities:

- mandatory medical examinations for all football athletes

- education of players, parents and coaches

- coaching of proper blocking and tackling techniques

- strengthening of the neck muscles

- $\quad$ strict enforcement of rules

- physician or athletic trainer coverage

- preparedness for all emergencies

- immediate medical attention for any player with signs of head trauma

Injury prevention or 'acceptable risk' can be achieved by minimizing extrinsic risk factors and counterbalancing intrinsic risk factors. Intrinsic factors include the developmental mindset along with biologic characteristics of the individual. Extrinsic factors include predictors of injury related to the activity or environment. In reality, the literature contains a paucity of actual preventative trials.

A cohort interventional analysis by Bixler and Jones [67] attempted to determine whether a warm-up and stretching session at half-time affected injury risk in the 3rd quarter of the game. The authors found a significant decrease in 3rd quarter sprains and strains, but no difference in total injuries. Preassignment of participating teams may have introduced bias since increased susceptibility by an individual team or a particular game may have skewed the results. 
Neck circumference and range of motion were studied in 40 high school football players [68]. No correlation was found between the athlete's neck size and range of motion. The authors speculate that proper fitting equipment, neck conditioning exercises and changes in the rules might reduce the risk of injury to the cervical spine region in football players. Although impingement of the helmet and facemask against the shoulder pads may restrict motion and tensile forces, the most dangerous mechanism of injury is an axial load to the partially flexed cervical spine.

Observations of high school football players over a 12-year period by Cahill and Griffith [6] suggested that a preseason conditioning program, consisting of cardiovascular stress, heat acclimatization, weight training, flexibility drills and agility exercises, reduced the number and severity of knee injuries. A follow-up study showed that a decrease in supervision of the quality of the preseason program did not affect the apparent benefits [59]. No exposure data were collected, and no other potential confounding variables were examined.

Despite the lack of true epidemiological research, the experiences of numerous authors provides some important recommendations that may prevent injuries or improve the care of the athlete:

- provide emergency medical services (physicians, athletic trainers, paramedics or emergency medical technicians) during games [69]

- match players by Tanner stage and development [70]

- encourage appropriate training and conditioning [70]

- properly fit equipment and footwear [70]

- $\quad$ educate coaches and parents [70]

- maintain playing fields [17]

- $\quad$ use of soccer-style shoes [17]

- allow only noncontact and controlled activities in practice $[17,63]$

- increase vigilance over technique during injury-prone preseason practices [17]

- delay return to full contact until complete recovery of injured players [63]

- teach fundamental blocking and tackling skills [39]

- $\quad$ strengthen the neck muscles [39]

- ensure qualified coaches to render emergency care prior to physician evaluation or emergency transport [39]

- $\quad$ forbid use of the head for initial contact [39]

In Garrick's opinion, no new items of equipment would significantly reduce football injuries [71].

According to the FIMS/WHO Ad Hoc Committee on Sports and Children, sport governing bodies should: monitor the level of intensity and categories of competition in their sports, prepare and maintain ongoing statistics of illness 
and injury, certify the credentials of coaches and determine standards for protective equipment, playing fields, and duration of competition.

\section{Suggestions for Further Research}

To make informed decisions about football injury prevention, risk must be reliably identified in relation to multiple variables. Comparison of injury incidence and risk factors requires well-designed injury epidemiology studies. Ideally, protocols involve the prospective analysis of a defined cohort by an experienced research team. Each study needs a standardized, strict definition of injury and medical terminology, diagnosis by a sports medicine professional, accurate measurement of player exposure, and data analysis based on injury per player play. Longer study duration may determine residual injury effects and cost. High quality epidemiology study design will allow assessment of numerous variables such as player size, rules, protective equipment and playing surface.

Football head-related fatalities, concussion, neck and spinal cord injuries have been reduced by rule changes and improved coaching of blocking and tackling techniques. An increased emphasis on research to test the efficacy of these and other preventative measures is needed.

Youth football leagues are typically organized by age or grade level with some position restrictions according to body weight. A better understanding of the association between injury risk and player age, physical maturity and body weight may promote prevention through validated matching strategies.

\section{Acknowledgment}

The author thanks Patricia J. Erwin of the Mayo Medical Library for her assistance with the literature review.

\section{References}

1 Landry GL: Sports injuries in childhood. Pediatr Ann 1992;21:165-168.

2 Gallagher SS, Finison K, Guyer B, Goodenough S: The incidence of injuries among 87,000 Massachusetts children and adolescents: Results of the 1980-1981 statewide childhood injury prevention program surveillance system. Am J Public Health 1984;74:1340-1347.

3 Mueller FO, Blyth CS: Can we continue to improve injury statistics in football? Phys Sportsmed 1984;12:79-83.

4 Hutchinson MR, Nasser R: Common sports injuries in children and adolescents. Medscape General Medicine 2000;2:http://www.medscape.com/viewarticle/408524. 
5 Mueller FO, Blyth CS: Football injury update - 1979 season. Improved conditioning, rule changes, and a helmet standard helped reduce football fatalities to an all-time low in 1979. Phys Sportsmed 1980;8:53-55.

6 Cahill BR, Griffith EH: Effect of preseason conditioning on the incidence and severity of high school football knee injuries. Am J Sports Med 1978;6:180-184.

7 Mueller FO, Blyth CS: An update on football deaths and catastrophic injuries. Phys Sportsmed 1986;14:139-42.

8 Culpepper MI, Niemann KMW: A comparison of game and practice injuries in high school football. Phys Sportsmed 1983;11:117-122.

9 Maroon JC, Steele PB, Berlin R: Football head and neck injuries - an update. Clin Neurosurg 1980;27:414-429.

10 Mueller FO, Blyth CS, Cantu RC: Catastrophic spine injuries in football. Phys Sportsmed $1989 ; 17$.

11 Dagiau RF, Dillman CJ, Milner EK: Relationship between exposure time and injury in football. Am J Sports Med 1980;8:257-260.

12 Lackland DT, Akers P, Hirata I Jr: High school football injuries in South Carolina: A computerized survey. JSC Med Assoc 1982;78:75-78.

13 Stocker BD, Nyland JA, Caborn DN, Sternes R, Ray JM: Results of the Kentucky high school football knee injury survey. J K Med Assoc 1997;95:458-464.

14 Stuart MJ, Morrey MA, Smith AM, Meis JK, Ortiguera CJ: Injuries in youth football: A prospective observational cohort analysis among players aged 9 to 13 years. [erratum appears in Mayo Clin Proc 2003 Jan;78:120.] Mayo Clin Proc 2002;77:317-322.

15 Turbeville SD, Cowan LD, Owen WL, Asal NR, Anderson MA: Risk factors for injury in high school football players. Am J Sports Med 2003;31:974-980.

16 DeLee JC, Farney WC: Incidence of injury in Texas high school football. Am J Sports Med 1992;20:575-580.

17 Halpern B, Thompson N, Curl WW, Andrews JR, Hunter SC, and Boring JR: High school football injuries: Identifying the risk factors. (Les lesions consecutives a la pratique du football americain scolaire: identification des facteurs de risque.) Am J Sports Med 1987;15:316-320.

18 Moretz A 3rd, Rashkin A, Grana WA: Oklahoma high school football injury study: A preliminary report. J Okla State Med Assoc 1978;71:85-88

19 Prager BI, Fitton WL, Cahill BR, Olson GH: High school football injuries: A prospective study and pitfalls of data collection. Am J Sports Med 1989;17:681-685.

20 Thompson N, Halpern B, Curl WW, Andrews JR, Hunter SC, Boring JR 3rd, McLeod WD: High school football injuries: Evaluation.[erratum appears in Am J Sports Med 1987 May-Jun;15:257.] Am J Sports Med 1987;15:117-124.

21 Linder MM, Townsend DJ, Jones JC, Balkcom IL, Anthony CR: Incidence of adolescent injuries in junior high school football and its relationship to sexual maturity. Clin J Sport Med 1995;5:167-170.

22 Garrick JG, Requa, RK: Injuries in high school sports. Pediatrics 1978;61:465-469.

23 Turbeville SD, Cowan LD, Asal NR, Owen WL, Anderson MA: Risk factors for injury in middle school football players. Am J Sports Med 2003;31:276-281.

24 Roser LA, Clawson DK: Football injuries in the very young athlete. Clin Orthop 1970;69:219-223.

25 Godshall RW: Junior league football: Risks versus benefits. J Sports Med 1975;3:139-144.

26 Goldberg B, Rosenthal PP, Nicholas JA: Injuries in youth football. Phys Sportsmed 1984;12:122-130.

27 Robey JM, Blyth CS, Mueller FO: Athletic injuries: Application of epidemiology methods. J Am Med Assoc 1971;217:184-189.

28 Porter CD: Football injuries. Phys Med Rehab Clin N Am 1999;10:95-115.

29 Wallace RB: Application of epidemiologic principles to sports injury research. Public Health Report 1985;100:586-588.

30 Noyes FR, Lindenfeld TN, Marshall MT: What determines an athletic injury (definition)? Who determines an injury (occurrence)? Am J Sports Med 1987;5:595-568.

31 Thompson RR: A study of the type and cost of football injuries. A single season in a Minnesota high school. Minn Med 1986;69:656-658.

32 Zoch TW, Cleveland DA, McCormick J, Toyama K, Nordstrom DL: Football injuries in a rural area. Wis Med J 1996;95:570-573. 
Pritchett JW: A claims-made study of knee injuries due to football in high school athletes. J Pediatr Orthop 1988;8:551-553.

34 Langburt W, Cohen B, Akhthar N, O’Neill K, Lee JC: Incidence of concussion in high school football players of Ohio and Pennsylvania. J Child Neurol 2001;16:83-85.

35 Chambers RB: Orthopaedic injuries in athletes (ages 6 to 17). Comparison of injuries occurring in six sports. Am J Sports Med 1979;7:195-197.

36 Radelet MA, Lephart SM, Rubinstein EN, Myers JB: Survey of the injury rate for children in community sports. Pediatrics 2002;110:1-11.

37 Godshall RW: Junior League Football: Risks versus benefits. Primary Care; Clinics in Office Practice 7:331-341.

38 Powell JW, Barber-Foss KD: Injury patterns in selected high school sports: A review of the 1995-1997 seasons. J Athl Train 1999;34:277-284.

39 Olson OC: Spokane study: High school football injuries. Phys Sportsmed 1979;7:75-82.

40 Albright JP, Moses JM, Feldick HG, Dolan KD, Burmeister LF: Nonfatal cervical spine injuries in interscholastic football. J Am Med Assoc 1976;236:1243-1245.

41 Mueller FO: Catastrophic head injuries in high school and collegiate sports. J Athl Train 2001;36: 312-315.

42 Mueller FO: Fatalities from head and cervical spine injuries occurring in tackle football: 50 years' experience. Clin Sports Med 1998;17:169-181.

43 Cantu RC,Mueller FO: Catastrophic football injuries: 1977-1998. Neurosurgery 2000;47: 673-675; discussion 675-677.

44 Goldhaber GM: A national survey about parent awareness of the risk of severe brain injury from playing football. J Athl Train 1993;28: 306-311.

45 McLain LG, Reynolds S: Sports injuries in a high school. Pediatrics 1989;84:446-450.

46 Powell JW, Barber-Foss KD: Traumatic brain injury in high school athletes.[comment]. J Am Med Assoc 1999;282:958-963.

47 Guskiewicz KM, Weaver NL, Padua DA, Garrett WE Jr: Epidemiology of concussion in collegiate and high school football players. Am J Sports Med 2000;28:643-650.

48 Mueller F, Blyth C: Epidemiology of sports injuries in children. Clin Sports Med 1982;1:343-352.

49 Gomez JE, Ross SK, Calmbach WL, Kimmel RB, Schmidt DR, Dhanda R: Body fatness and increased injury rates in high school football linemen. Clin J Sport Med 1998;8:115-120.

50 Kaplan TA, Digel SL, Scavo VA, Arellana SB: Effect of obesity on injury risk in high school football players. Clin J Sport Med 1995;5:43-7.

51 Clark JL, Challop RS, McCabe EB: Predicting lower extremity injuries in high school football players. J Am Med Assoc 1971;217:1552-1553.

52 Marzo JM, Simmons EH, Whieldon TJ: Neck injuries to high school football players in Western New York State. NY State J Med 1991;91:46-49.

53 Thompson NJ, Morris RD: Predicting injury risk in adolescent players: The importance of psychological variables. J Pediatr Psychal 1994;19:415-429.

54 Coddington RD, Troxell JR: Effect of emotional factors on football injury rates - A pilot-study. J Human Stress 1980;6:3-5.

55 Cooper DL: High school football injuries. (editorial). South Med J 1976;69:1257.

56 Lawrence DW, Stewart GW, Christy DM, Gibbs LI, Ouellette M: High school football-related cervical spinal cord injuries in Louisiana: The athlete's perspective. J L State Med Soc 1997;149: 27-31.

57 Gerberich SG, Priest JD, Boen JR, Straub CP, Maxwell RE: Concussion incidences and severity in secondary school varsity football players. Am J Public Health 1983;73:1370-1375.

58 Heck JF: The incidence of spearing by ball carriers and their tacklers during a high school football season; in Hoerner EF (ed): Head and Neck Injuries in Sports. Philadelphia, American Society for Testing \& Materials, 1994, pp 239-249.

59 Cahill BR, Griffith EH, Sunderlin J, Madden T, Weltman A: Effect of preseason conditioning. High school football knee injuries. IMJ Ill Med J 1984;166:356-358.

60 Andresen BL, Hoffman MD, Barton LW: High school football injuries: Field conditions and other factors. Wis Med J 1989;88:28-31.

61 Adkison JW, Requa RK, Garrick JG: Injury rates in high school football. A comparison of synthetic surfaces and grass fields. Clin Orthop 1974;99:131-136. 
62 Bramwell ST, Garrick JG, Requa RK: High school football injuries: A pilot comparison of playing surfaces. Med Sci Sports 1972;4:166-169.

63 Mueller FD, Blyth CS: North Carolina high school football injury study: Equipment and prevention. J Sportsmed 1974;2:1-10.

64 Torg JS, Quedenfeld T: Effect of shoe type and cleat length on incidence and severity of knee injuries among high school football players. Res Q 1971;42:203-211.

65 Lambson RB, Barnhill BS, Higgins RW: Football cleat design and its effect on anterior cruciate ligament injuries: A three-year prospective study. Am J Sports Med 1996;24:155-159.

66 Deppen RJ, Landfried MJ: Efficacy of prophylactic knee bracing in high school football players. J Orthop Sports Phys Ther 1994;20:243-246.

67 Bixler B, Jones RL: High-school football injuries: Effects of a post-halftime warm-up and stretching routine. Fam Pract Res J 1992;12:131-139.

68 Pearl AJ, Mayer PW: Neck motion in the high school football player. Am J Sports Med 1979;7:231-233.

69 Silverstein BM: Injuries in youth league football. Phys Sportsmed 1979;7:105-108;111.

70 Rome ES: Sports-related injuries among adolescents: When do they occur, and how can we prevent them? Pediatr Rev 1995;16:184-187; quiz 188.

71 Garrick, JG: The facts about school athletic injuries - A conversation with Dr. James Garrick. NASSP Bulletin 1981;65:43-49.

Michael J. Stuart, MD

Mayo Clinic, 200 First Street SW

Rochester MN 55905 (USA)

Tel. +1 507284 3462, Fax +1 507284 5539, E-Mail stuart.michael@mayo.edu 